\title{
GAMBARAN MUSCULI FACIALIS PADA EKSPRESI WAJAH DAN EMOSI DENGAN MENGGUNAKAN FACIAL ACTION CODING SYSTEM PADA CALON PRESIDEN JOKOWI
}

\author{
${ }^{1}$ Friska G. Batoteng \\ ${ }^{2}$ Taufiq F. Pasiak \\ ${ }^{2}$ Shane H. R. Ticoalu
}

\author{
${ }^{1}$ Kandidat Skripsi Fakultas Kedokteran Universitas Sam Ratulangi Manado \\ ${ }^{2}$ Bagian Anatomi-Histologi Fakultas Kedokteran Universitas Sam Ratulangi Manado \\ Email: fbatoteng11_077@ymail.com
}

\begin{abstract}
Facial expression recognition is one way to recognize emotions which has not received much attention. Muscles that form facial expressions known as musculli facial, muscles that move the face and form human facial expressions: happy, sad, angry, fearful, disgusted and surprised which are the six basic expressions of human emotion. Human facial expressions can be measured using FACS (Facial Action Coding System). This study aims to determine the facial muscles which most frequently used and most rarely used, and determine the emotion expression of Jokowi, a presidential candidate, through assessment of the facial muscles using FACS. This study is a retrospective descriptive study. The research samples are the whole photo of Jokowi's facial expression at first presidential debate in 2014, about 30 photos. Samples were taken from a video debate and confirmed to be a photo using Jokowi's facial expressions which then further analyzed using FACS. The research showed that the most used action units and facial muscle is AU 1 whose work on frontal muscle pars medialis (14.75\%). The least appear muscles on Jokowi's facial expressions were musculus orbicularis oculi, pars palpebralis and AU 24 musculus obicularis oris (0.82\%). The dominant facial expressions was seen in Jokowi was sad facial expression (36.67\%).
\end{abstract}

Keywords: musculi facialis, facial expression, expression of emotion, FACS

\begin{abstract}
Abstrak: Pengenalan ekspresi wajah adalah salah satu cara untuk mengenali emosi yang belum banyak diperhatikan. Otot-otot yang membentuk ekspresi wajah yaitu musculli facialis yang merupakan otot-otot penggerak wajah dan membentuk ekspresi - ekspresi wajah manusia yaitu bahagia, sedih, marah, takut, jijik dan terkejut yang merupakan 6 dasar ekspresi emosi manusia. Ekspresi wajah manusia dapat diukur dengan menggunakan parameter FACS (Facial Action Coding System). Penelitian ini bertujuan untuk mengetahui musculi facialis yang paling sering digunakan dan yang paling jarang digunakan, serta untuk menentukan ekspresi emosi calon presiden Jokowi. Desain penelitian ini yaitu penelitian deskriptif dengan retrospektif. Sampel penelitian ialah seluruh foto ekspresi wajah Jokowi saat debat calon presiden pertama tahun 2014 sebanyak 30 foto. Sampel diambil dari video debat dan dikonfirmasi menjadi foto kemudian dianalisis lebih lanjut menggunakan FACS. Penelitian ini didapatkan hasil bahwa Musculi yang paling banyak digerakkan, yaitu Musculi frontalis pars medialis (14,75\%). Musculi yang paling sedikit muncul pada ekspresi wajah Jokowi yaitu musculus orbicularis oculi, pars palpebralis dan musculus obicularis oris (0,82\%). Ekspresi wajah yang dominan dinampakkan oleh Jokowi merupakan ekspresi wajah sedih (36,67\%).
\end{abstract}

Kata kunci: musculi facialis, ekspresi wajah, ekspresi emosi, FACS 
Neurosains adalah ilmu yang mempelajari sistem saraf, terutama mempelajari neuron atau sel saraf, ${ }^{1}$ dalam hal ini otak. Otak pada orang dewasa terdiri dari batang otak, diensefalon, serebrum dan serebelum. ${ }^{2}$ Otak adalah pusat kendali untuk merasakan sensasi, menghubungkannya satu dengan yang lain dan berdasarkan informasi yang tersimpan, membuat keputusan dan mengambil tindakan. Otak juga merupakan pusat kecerdasan, emosi, perilaku, dan memori. ${ }^{3}$

Ekspresi emosi diatur oleh sistem limbik. Sistem limbik bukanlah suatu struktur terpisah tetapi suatu cincin struktur-struktur otak depan yang mengelilingi batang otak dan saling berhubungan melalui jalur-jalur neuron rumit. Struktur ini mencakup bagian lobuslobus korteks serebri, nukleus basal, talamus, dan hipotalamus. ${ }^{4}$ Ada banyak cara untuk mengekspresikan emosi seperti lewat ekspresi wajah dan suara, lewat katakata dan seni seperti musik. ${ }^{5}$

Pengenalan ekspresi wajah merupakan salah satu cara untuk mengenali emosi. Karena ekspresi wajah merupakan hal yang paling kuat, alami dan cepat untuk menyampaikan emosi atau perasaan seseorang. Banyak hal dapat diketahui hanya dengan melihat ekspresi seseorang seperti niat, kepribadian, hubungan sosial dan benda-benda yang ada di lingkungan. ${ }^{5}$ Otot-otot yang membentuk ekspresi wajah dikenal sebagai musculi facialis yang merupakan otot-otot penggerak wajah, sebagai contoh musculi zigomaticus major dan minor berorigo pada tulang zigomaticus dan berinsersio pada sudut mulut berfungsi menarik sudut mulut ke atas dan keluar. 6

Ada enam ekspresi emosi dasar yaitu kebahagiaan, terkejut, takut, jijik, marah, dan kesedihan. Para peneliti dari Ohio State University telah mengkategorikan 21 ekspresi wajah yang berbeda dari enam emosi dasar. ${ }^{7}$

Pengenalan ekspresi wajah adalah salah satu bentuk representasi kecerdasan manusia yang dapat digunakan untuk mendeteksi kondisi emosi seseorang. ${ }^{8}$
Ekman dan Friesen mengembangkan sistem yang paling komprehensif untuk sintesa ekspresi wajah berbasis apa yang mereka sebut Action Units (AU). Mereka mendefinisikan sistem pengkodean aksi wajah atau Facial Action Coding System (FACS). FACS terdiri atas 46 AU, yang menggambarkan gerakan wajah dasar. Otot-otot wajah menggambarkan secara detail pengaruh masing-masing AU pada ciri wajah. ${ }^{9}$ Setiap ekspresi wajah dapat secara akurat diwakili oleh sejumlah otot pada wajah, observasi inilah yang kemudian mendasari dibentuknya dan dikembangkan FACS. $^{10}$ Ekman mengatakan bahwa analisis terhadap pergerakan otot wajah (dikenal sebagai AU di FACS) adalah analisis deskriptif dari tingkah laku, sementara analisis ekspresi wajah seperti marah atau senang adalah suatu proses untuk membuat dugaan tentang keadaan psikologis yang mendasari. $^{11}$

Pada tahun 2002 dilakukan update terhadap FACS yang memungkinkan representasi yang lebih akurat terhadap ekspresi wajah (Ekman Paul dan Friesen, 2002). ${ }^{12,13}$

Berdasarkan penelitian sebelumnya bahwa rata-rata recognition rates dari FACS adalah 96,4\% (95,4\% jika tidak termasuk ekspresi netral) untuk upper face AU dan 96,7\% (95,6\% jika tidak termasuk ekspresi netral) untuk lower face AU (Tian Y, Mellon C dan Cohn JF, 2001). ${ }^{14}$

Berdasarkan uraian di atas peneliti tertarik untuk meneliti tentang adakah gambaran musculi facialis pada ekspresi wajah dan emosi dengan menggunakan Facial Action Coding System?

\section{METODE PENELITIAN}

Jenis penelitian yang digunakan dalam penelitian ini ialahpenelitian deskriptif melalui pendekatan retrospektif. Penelitian ini dilakukan di bagian AnatomiHistologi Fakultas Kedokteran Universitas Sam Ratulangi pada bulan Oktober 2014 November 2014. Sampel penelitian ini ialah foto ekspresi wajah Jokowi saat debat calon presiden putaran pertama tahun 2014 
yang masing-masing berjumlah 30 foto yang diambil secara purposive sampling dengan kriteria inklusi, yaitu foto wajah Prabowo dan Jokowi, memperlihatkan wajah dari depan, dan tampak mulut, pipi, hidung, mata, dan dahi, serta kriteria eksklusi, yaitu foto yang rusak dan tidak jelas (blur).

Cara pengambilan data dilakukan dengan Snapshot pada berbagai rentang waktu hasil pengamatan video debat calon presiden dengan cara menggunakan aplikasi KMPlayer sehingga dihasilkan beberapa foto, kemudian dilakukan pemotongan foto dengan menggunakan aplikasi photoscape sehingga kualitas gambar dalam foto dapat terfokus dan terlihat lebih jelas. Setelah didapatkan data berupa foto, dilakukan penilaian dengan menggunakan Facial Action Coding System untuk kemudian dianalisis lebih lanjut.

\section{HASIL PENELITIAN}

Tabel 1. Karakteristik subjek penelitian berdasarkan waktu debat calon presiden

\begin{tabular}{cccc}
\hline Waktu debat (menit) & Rentang waktu (menit) & Frekuensi & Persentase (\%) \\
\hline \multirow{2}{*}{$00-33$} & $10: 30-13: 38$ & 9 & 30,00 \\
& $20: 37-22: 10$ & 1 & 3,33 \\
$33-57$ & $41: 56-43: 45$ & 4 & 13,33 \\
& $48: 50-43: 45$ & 4 & 13,33 \\
$57-110$ & $01: 31: 31-01: 35: 25$ & 6 & 20,00 \\
& $01: 40: 19-01: 42: 27$ & 6 & 20,00 \\
\hline \multirow{2}{*}{5} & Jumlah & 30 & 100 \\
\hline
\end{tabular}

Karakteristik subjek penelitian berdasarkan waktu debat calon presiden Subjek penelitian yang terdapat dalam penelitian ini ialah foto ekspresi wajah Jokowi saat debat pertama calon presiden tahun 2014.

Tabel 2. Karakteristik subjek penelitian berdasarkan pergerakan musculi facialis

\begin{tabular}{clcc}
\hline AU & \multicolumn{1}{c}{ Otot yang bekerja (Musculi facialis) } & Frekuensi & $\begin{array}{c}\text { Persentase } \\
(\mathbf{\%})\end{array}$ \\
\hline 1 & Frontalis pars medialis & 18 & 14,75 \\
2 & Frontalis pars lateralis & 8 & 6,56 \\
4 & Corrugator supercilii & 8 & 6,56 \\
5 & Levator palpebrae superioris & 8 & 6,56 \\
6 & Orbicularis oculi, pars orbitalis & 15 & 12,30 \\
7 & Orbicularis oculi, pars palpebralis & 1 & 0,82 \\
9 & Levator labii superioris alaque nasi & 5 & 4,10 \\
10 & Levator labii superioris & 5 & 4,10 \\
11 & Zygomaticus minor & 12 & 9,84 \\
12 & Zygomaticus major & 6 & 4,92 \\
15 & Depressor anguli oris (a.k.a. triangularis) & 11 & 9,02 \\
17 & Mentalis & 8 & 6,56 \\
24 & Obicularis oris & 1 & 0,82 \\
25 & Depressor labii inferioris or relaxation of mentalis or orbicularis oris & 14 & 11,48 \\
26 & Masseter, relaxed temporalis and internal pterygoid & 2 & 1,64 \\
\hline Jumlah & & 122 & 100 \\
\hline
\end{tabular}


Tabel 3. Karakteristik subjek penelitian berdasarkan ekspresi emosi

\begin{tabular}{ccc}
\hline Ekspresi emosi & Frekuensi & $\begin{array}{c}\text { Persentase } \\
\text { (\%) }\end{array}$ \\
\hline Senang & 6 & 20,00 \\
Sedih & 11 & 36,67 \\
Takut & - & - \\
Marah & 1 & 3,33 \\
Terkejut & 7 & 23,33 \\
Jijik & 5 & 16,67 \\
\hline Jumlah & 30 & 100,00 \\
\hline
\end{tabular}

\section{BAHASAN}

Ekspresi wajah merupakan emosi dasar dari seseorang, kita dapat mengenali dan mengerti emosi orang lain, selain mengungkapkan emosi secara sendiri sendiri, juga dapat mengungkapkan kombinasi emosi.

Pada penelitian ini digunakan subjek penelitian ekspresi wajah Jokowi pada saat debat pertama calon presiden Republik Indonesia. Penelitian ini menggunakan parameter Facial Action Coding System (FACS) yang merupakan sistem pengkodean aksi wajah. FACS terdiri atas 46 AU, yang menggambarkan gerakan wajah dasar yang berbasis pada aktivitas otot dan menggambarkan detail pengaruh masing-masing AU pada ciri wajah.

Pada Tabel 1, ekspresi yang muncul pada setiap rentang waktu berbeda-beda walaupun hanya 1 detik saja. Pada tabel 3 frekuensi ekspresi yang paling banyak yaitu 9 frekuensi dengan rentang waktu debat pada menit ke 10:30 - 13:38 30,00\%. Penelitian sebelumnya menunjukkan bahwa pidato kepresidenan biasanya mempengaruhi pendengarnya secara emosional khususnya apabila ekspresi wajah yang nampak tidak sesuai dengan konteksnya. Sebuah penelitian meneliti bagaimana sebuah ekspresi wajah sangat cepat dan halus (ekspresi yang kurang dari 1 detik sebagai mikroekspresi) yang terdapat dalam pidato yang dibawakan oleh pemimpin-pemimpin politik mempengaruhi emosi pendengarnya. Dalam penelitian tersebut diambil 7 ekspresi (kurang dari 1 detik dari pidato lewat televisi dengan durasi 12 menit) yang dibawakan oleh presiden George $\mathrm{H}$. W. Bush mengenai komitmen AS ditahun 1990 sebagai respon terhadap invasi di Kuwait. FACS mengidentifikasi semua ekspresi yang mengandung komponen dari senyum (sudut mulut tertarik AU 12), dan pada beberapa kasus pergerakan wajah lainnya yang berhubungan dengan marah atau jijik. Penelitian tersebut dilakukan pada 206 mahasiswa dan menunjukkan dan menunjukkan keadaan perubahan emosional sebagai respon terhadap mikroekspresi tersebut. Secara khusus partisipan yang melihat mikroekspresi ini merasa sedikit terancam emosi meskipun mikroekspresi yang sangat singkat dapat mempunyai pengaruh yang sangat signifikan pada pendengar dari pidato politik. $^{15}$

Pada Tabel 2 dan 3, didapatkan hasil yang berkaitan yaitu pada tabel 5 berdasarkan karakteristik otot wajah yang paling banyak bekerja yaitu musculus frontalis pars medialis (AU 1) dengan frekuensi 18 kali (14,75\%), musculus orbicularis oculi pars orbitalis (AU 6) dengan frekuensi 15 kali (12,3\%), musculus zygomaticus minor (AU 11) dengan frekuensi 12 kali (9,84\%), musculus depressor anguli oris (AU 15) dengan frekuensi 11 kali (9,02\%), dan musculus mentalis (AU 17) dengan frekuensi 8 kali $(6,56 \%)$ yang merupakan pembentuk ekspresi sedih.

Ekspresi-ekspresi yang ditunjukkan oleh Jokowi tidak hanya ekspresi sedih saja tetapi ada ekspresi senang, marah, terkejut dan jijik. Ekspresi emosi yang ditampilkan oleh seseorang akan mempengaruhi orang yang melihatnya, seperti penelitian pada pembawa berita pada tahun 1986 tentang pengaruh ekspresi wajah pembawa berita terhadap kebiasaan memilih penonton menemukan bahwa pemilih yang biasanya menonton pembawa berita yang 
menampilkan wajah yang memihak biasanya lebih cenderung untuk memilih kandidat yang disenyumi pembawa berita. 16

\section{SIMPULAN}

Dari 30 sampel foto Musculi facialis yang paling sering digunakan pada calon presiden Jokowi melalui penilaian Action Unit pada Facial Action Coding System yaitu musculi frontalis pars medialis dan Musculi facialis yang paling jarang digunakan yaitu musculi orbicularis oculi, pars palpebralis dan musculi orbicularis oris, serta ekspresi yang paling banyak muncul yaitu ekspresi sedih.

\section{DAFTAR PUSTAKA}

1. Pasiak Taufiq. Tuhan Dalam Otak Manusia. Bandung: Mizan; 2012:132,217.

2. Premkumar K. The Massage Connection: Anatomy and Physiology 2nd ed. Philadelphia: Lippincot Williams \& Wilkins; 2004:348

3. Tortora GJ, Derrickson B. Principles Of Anatomy And Physiology. Edisi 12. USA: John Wiley \& Sons, Inc. 2009: 495.

4. Sherwood L. Fisiologi Manusia. Edisi 6. In: Brahm U. Yesdelina N, editor. Jakarta: EGC; 2011.

5. Ketner D, Ekman P. Introduction: Expression Of Emotion, RJ. Scherer K R, Gold H H (Eds), Handbook Of Affective Sciences. New York: Oxford University press.2003:411-4.

6. Sloane Ethel. Anatomi dan Fisiologi untuk Pemula. Jakarta: EGC; 2003:131-32.

7. Ekspresi Emosi Wajah tidak Universal [cited 2014 Sep 19] Available from: http://jurnal.kesimpulan.com/2012/04 /ekspresi-emosi-wajah-tidakuniversal.html
8. Ghozali MZ, Bilfaqih Y, Jazidie A. Pengenalan Emosi Akademis Menggunakan Jaringan Syaraf Tiruan untuk Mendukung Personalisasi Sistem E-Learning. Surabaya: ITS 2010; 1.

9. Cohn JF, Ambadar Z, Ekman P. Observer-Based Measurement of Facial Expression With the Facial Action Coding System [cited Oct 11] Available from: http://www.pitt.edu/ jeffcohn/biblio/ Coan\%20013\%20chap13.pdf.

10. Chew SW. Recognition Facial Expression With Noisy Data. [Thesis].[Brisbane]: Oueensland University;2013.

11. The Facial Expression Coding System (FACES) [cited Oct 11] Available from:http://socrates.berkeley.edu/ akr ing/FACES\%2520manual.pdf\&prev= search

12. Ekman P, Friesen. FACS - Facial Action Coding System. [cited 2014 Oct 6] Available from: http://www.cs.cmu.edu/ face/facs.ht $\mathrm{m}$

13. Ekman P, Friesen WV, and Hager JC.The new (2002) Facial Action Coding System (FACS). [cited 2014 Oct 6] Available from: http://faceand-

emotion.com/dataface/facs/new_versi on.jsp

14. Tian Y, Mellon C, Cohn JF. Recognition Action Unit For Facial Expression Analysis. IEEE. 2001;23:97-115.

15. Mullen, Brian, et. al. Newscasters' Facial Expressions and Voting Behavior of Viewers: Can a Smile Elect a President? Journal of Personality and Social Psychology. 1986;51(2):291295.

16. McCandless J, Connor S. Nonverbal Communication: Encoding and Decoding Facial Expressions. Needham: Olin College. 2012; 27-30. 